\section{Influence of Temporary Cements on the Bond Strength of Self-Adhesive Cement to the Metal Coronal Substrate}

Raniel Fernandes Peixoto, Caio Rocha de Aguiar, Eduardo Santana Jacob, Ana Paula Macedo, Maria da Gloria Chiarello de Mattos, Rossana Pereira de Almeida Antunes
Department of Dental Materials and Prosthodontics, School of Dentistry of Ribeirão Preto, USP - Universidade de São Paulo, Ribeirão Preto, SP, Brazil

Correspondence: Rossana Pereira de Almeida Antunes, Avenida do Café, s/n, Monte Alegre, 14040-904, Ribeirão Preto, SP, Brasil. Tel: +55-163315-4411. e-mail: rpaa@forp.usp.br

\begin{abstract}
This research evaluated the influence of temporary cements (eugenol-containing [EC] or eugenol-free [EF]) on the tensile strength of $\mathrm{Ni}$-Cr copings fixed with self-adhesive resin cement to the metal coronal substrate. Thirty-six temporary crowns were divided into 4 groups ( $n=9$ ) according to the temporary cements: Provy, Dentsply (eugenol-containing), Temp Cem, Vigodent (eugenol-containing), RelyX Temp NE, 3M ESPE (eugenol-free) and Temp Bond NE, Kerr Corp (eugenol-free). After $24 \mathrm{~h}$ of temporary cementation, tensile strength tests were performed in a universal testing machine at a crosshead speed of $0.5 \mathrm{~mm} / \mathrm{min}$ and $1 \mathrm{kN}(100 \mathrm{kgf})$ load cell. Afterwards, the cast metal cores were cleaned by scraping with curettes and air jet. Thirty-six $\mathrm{Ni}-\mathrm{Cr}$ copings were cemented to the cast metal cores with self-adhesive resin cement (RelyX U200, 3M ESPE). Tensile strength tests were performed again. In the temporary cementation, Temp Bond NE $(12.91 \pm 2.54)$ and Temp Cem $(12.22 \pm 2.96)$ presented the highest values of tensile strength and were statistically similar to each other $(p>0.05)$. Statistically significant difference $(p<0.05)$ was observed only between Provy $(164.44 \pm 31.23)$ and Temp Bond NE $(88.48 \pm 21.83)$ after cementation of $\mathrm{Ni}-\mathrm{Cr}$ copings with self-adhesive resin cement. In addition, Temp Cem (120.68 \pm 48.27$)$ and RelyX Temp NE (103.04 \pm 26.09$)$ showed intermediate tensile strength values. In conclusion, the Provy eugenol-containing temporary cement was associated with the highest bond strength among the resin cements when $\mathrm{Ni}-\mathrm{Cr}$ copings were cemented to cast metal cores. However, the eugenol cannot be considered a determining factor in increased bond strength, since the other tested cements (1 eugenol-containing and 2 eugenol-free) were similar.
\end{abstract}

Key Words: dental prosthesis, temporary cements, resin cements, tensile strength.

\section{Introduction}

Indirect restorations are recommended in oral rehabilitation when there is great loss of tooth structure (1). Advances in adhesive dentistry have been followed by an increase in choice of resin cements that exhibit greater bond strength and reduced solubility when compared with non-adhesive luting cements and can assure greater longevity of the indirect restorations $(2,3)$. However, indirect restoration procedure requires more clinical time and use of temporary restorations and cements (4).

A temporary restoration is fixed into the prepared tooth and the bond strength of the cement should be adequate to retain the restoration in function, but small enough to allow easy removal of the provisional restoration before cementing the final restoration (5). Complete elimination of temporary cement from tooth or metal surfaces (cast cores and copings) is difficult and the residual particles may interfere with adhesive properties of resin cements $(3,6)$.

The presence of residual particles of the temporary cements on substrate is a potential risk of contamination that may affect the adhesion of resin cement, causing reduction of the surface free energy $(4,7,8)$. Additionally, the use of eugenol-containing temporary cements before adhesive cementation has been associated with lower bond strength of resin cements, affecting the polymerization of monomers and the physical properties of the resin cement (9-14). However, some studies suggested that temporary cements, regardless of the eugenol content, reduce the bond strength of resin cements $(15,16)$.

The influence of eugenol-containing temporary cements on the bond strength of adhesive systems and resin cements to dentin was largely studied in the literature $(3,4,6-10)$; however, to our knowledge and according to a Pubmed search (August 24, 2015; search terms: ["temporary cements" or "provisional cements"] and "bond strength of resin cement" and "metal core"), there are no studies in literature evaluating the association of eugenol-containing temporary cements with changes in the tensile strength of resin cements in metal coronal substrate.

This study evaluated the influence of temporary cements (containing eugenol or eugenol-free) on the tensile strength of $\mathrm{Ni}$-Cr copings cemented with self-adhesive resin cement to the metal coronal substrate. The work hypothesis was that eugenol-containing or eugenol-free temporary 
cements would not interfere in the bond strength of the self-adhesive resin cement to metal coronal substrate.

\section{Material and Methods}

\section{Manufacture of Metal Cores}

Thirty-six $\mathrm{Ni}-\mathrm{Cr}$ metal cores were obtained from a stainless steel model according to methodology described by Peixoto et al. (17). This model presented a crown preparation with about 4 degrees axial taper, a height of $8.28 \mathrm{~mm}$ and a chamfer finish line. The occlusal surface was flat with a diameter of $5.58 \mathrm{~mm}$ and cervical shoulder of $9.16 \mathrm{~mm}$.

Acrylic resin custom trays were manufactured and the model was duplicated using condensation silicone impression material (Optosi ${ }^{\circledR} /$ Xantopren $^{\circledR}$, Heraeus Kulzer, Germany). The molding process was conducted with a surveyor to standardize the process of molding.

Molten modeling wax was poured inside the mold to make replicas of the dies (metal cores). The replicas were cast by the lost wax method, using an oxygen-gas flame and subsequent injection of the $\mathrm{Ni}-\mathrm{Cr}$ dental alloy (Verabond II, Aalba Dent, Cordelia, CA, USA) by centrifugation. Metal cores were included in rigid PVC rings with acrylic resin Dencrilon (Dencril, Pirassununga, SP, Brazil) (Fig. 1) and the

\section{Fabrication of Temporary Crowns}

A temporary crown in acrylic resin Duralay (Reliance Dental MFG Co., Worth, IL, USA) containing a hole to adapt it in the universal testing machine was manufactured on one of these metal cores (Fig. 2A). Next, a silicone matrix (Zetalabor, Zhermack, Rovigo, Italy) was fabricated to standardize all temporary crowns $(n=36)$ (Figs. 2B and
2C). Powder and liquid (2:1) were mixed for $5 \mathrm{~s}$ with a \#7 spatula and inserted into the silicone matrix (Fig. 2D). To avoid incorporation of air bubbles, the mixture was slowly inserted under vibration until total filling of the die.

\section{Temporary Cementing Procedure}

Temporary crowns were divided into 4 groups $(n=9)$ according to temporary cements: Provy (Dentsply, Petrópolis, RJ, Brazil; eugenol-containing), Temp Cem (Vigodent, Rio de Janeiro, RJ, Brazil; eugenol-containing), RelyX ${ }^{\mathrm{TM}}$ Temp NE (3M ESPE, Seefeld, Germany; eugenolfree) and Temp Bond ${ }^{\oplus}$ NE (Kerr Corp, Orange, CA, USA; eugenol-free). The preparation of cements followed the manufacturers' recommendations. A metal device $(5 \mathrm{~kg})$ attached to the top of the mobile rod of a modified surveyor was used to maintain constant pressure during $24 \mathrm{~h}$ (Fig. 3), considering the late setting reaction of cement according

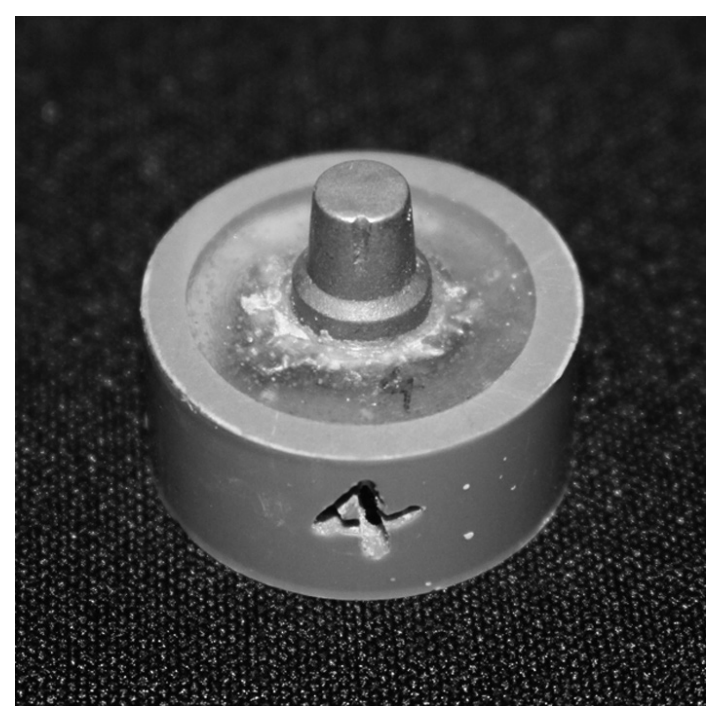

Figure 1. Metal cores included in PVC rings.
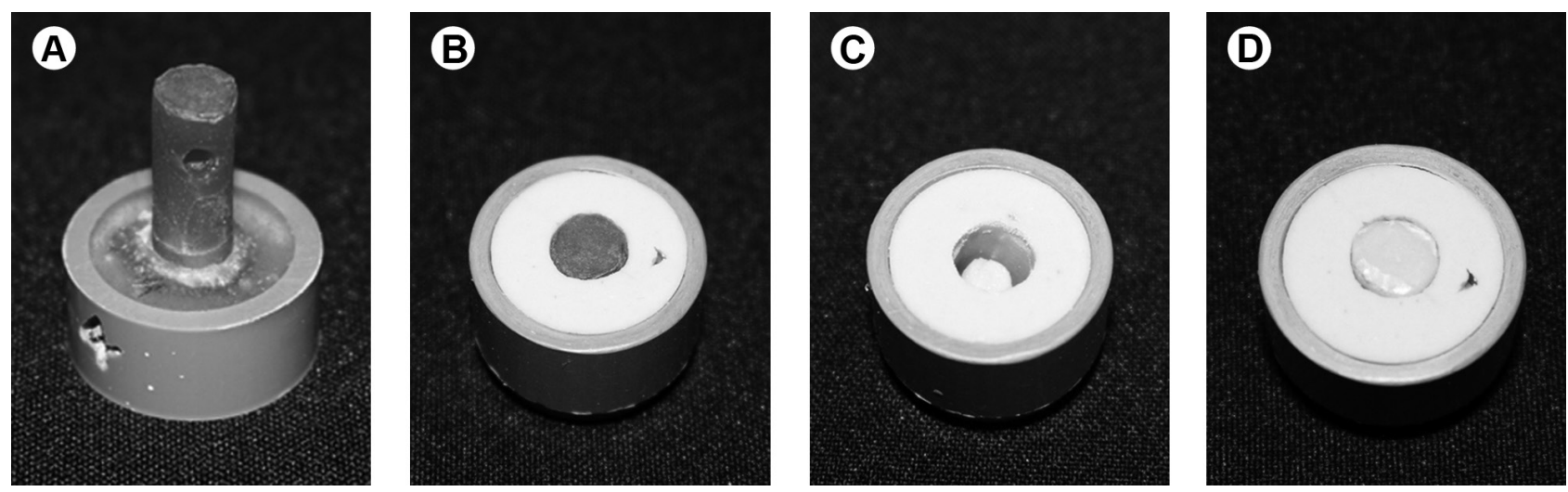

Figure 2. Fabrication of temporary crowns in acrylic resin Duralay (A). Temporary crown molding (B) to manufacture a silicone matrix (C) and to standardize the preparation of all temporary crowns (D). 
to manufacturer's recommendation.

\section{Tensile Strength Testing}

Tensile strength test was performed in a universal testing machine (EMIC, São José dos Pinhais, PR, Brazil) at a crosshead speed of $0.5 \mathrm{~mm} / \mathrm{min}$ and $1 \mathrm{kN}$ (100 kgf) load cell. The tensile strength was recorded in $\mathrm{N}$.

\section{Fabrication of $\mathrm{Ni}-\mathrm{Cr}$ Copings}

Plaster dies were produced from the cast metal cores to obtain the $\mathrm{Ni}-\mathrm{Cr}$ copings according to the methodology described by Peixoto et al. (17). The metal cores were fixed in a rigid plastic ring with chemically activated acrylic resin, molded with condensation silicone impression material (Optosi ${ }^{\oplus} /$ Xantopren $^{\oplus}$ ) and waxed. A capsule-matrix overlapping $1 \mathrm{~mm}$ the height of the plaster dies was used

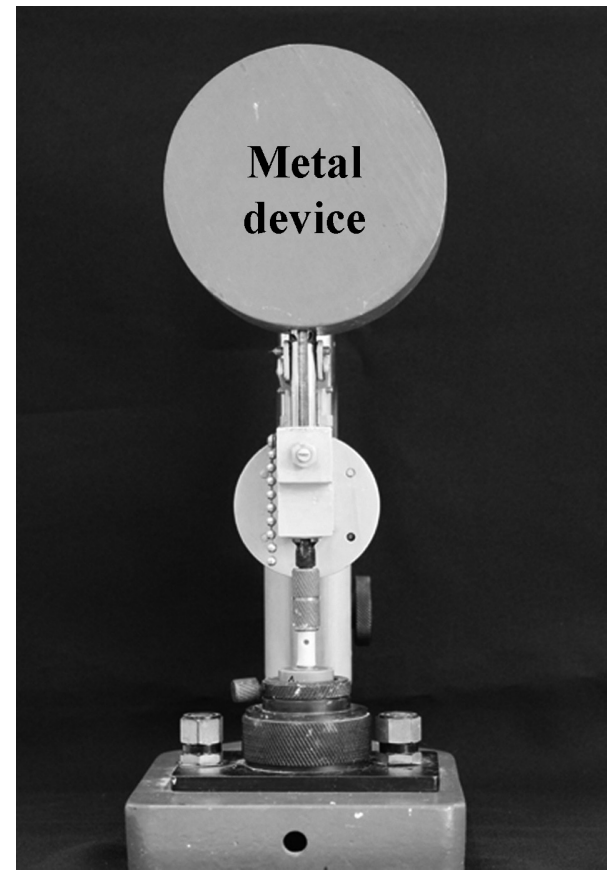

Figure 3. Modified surveyor used to maintain constant pressure on the specimen during the setting time of the cement. to standardize the wax patterns thickness. The resulting wax patterns were cast with $\mathrm{Ni}-\mathrm{Cr}$ dental alloy (Verabond II) in a Discovery Plasma Ar-arc vacuum-pressure casting machine (EDG, São Carlos, SP, Brazil). The $\mathrm{Ni}-\mathrm{Cr}$ copings $(n=36)$ were divested immediately after cooling at room temperature, sandblasted with $80-\mu \mathrm{m}$ aluminum oxide particles under $80 \mathrm{lb} / \mathrm{in}^{2}\left(5.62 \mathrm{kgf} / \mathrm{cm}^{2}\right)$ pressure, and divided into 4 groups for definitive cementation.

\section{Definitive Cementing Procedure}

After tensile strength test of temporary crowns, the metal cores were cleaned with curettes and air jet simulating a clinical situation. The $\mathrm{Ni}-\mathrm{Cr}$ copings were cemented with self-adhesive resin cement (RelyX U200; 3M ESPE, Seefeld, Germany) and the same modified surveyor with metal device (Fig. 3) was used to maintain constant pressure during the polymerization of the cement. Tensile strength test was performed again as previously described.

\section{Statistical Analysis}

The results were analyzed statistically using the Statistical Package for the Social Sciences (version 17.0; SPSS Inc., Chicago, IL, USA). To evaluate differences between the various groups two-way ANOVA and Bonferroni test were used with a significance level of $5 \%$.

\section{Results}

The statistical results of tensile strength $(\mathrm{kgf})$ of the groups fixed with temporary cements are presented in Table 1. Temp Bond NE (12.91 \pm 2.54$)$ and Temp Cem (12.22 \pm 2.96$)$ presented similar and the highest values of tensile strength $(p>0.05)$ and Provy the lowest value $(p<0.05)$. Temp Bond NE showed intermediate value compared with Temp Cem and Temp Bond NE groups ( $p>0.05$ ).

After cementation with self-adhesive resin cement, Provy $(164.44 \pm 31.23)$ presented significantly higher tensile strength when compared with Temp Bond NE (88.48 \pm 21.83$)$ $(p<0.05)$. Provy was statistically similar to Temp Cem $(120.68 \pm 48.27)(p>0.05)$ and RelyX Temp NE (103.04 \pm 26.09$)$ ( $>0.05)$ (Table 2).
Table 1. Tensile strength values (kgf) of the eugenol-containing (EC) or eugenol-free (EF) temporary cements

\begin{tabular}{lcccc}
\hline Group (n=9) & Mean (SD) & Minimum & Median (Q75 - Q25) & Maximum \\
\hline Provy (EC) & $6.98(1.94) \mathrm{b}$ & 5.04 & $6.88(7.30-5.42)$ & 11.57 \\
Temp Cem (EC) & $12.22(2.96) \mathrm{a}$ & 5.93 & $12.66(14.14-10.63)$ & 16.10 \\
RelyX Temp NE (EF) & $9.01(2.51) \mathrm{ab}$ & 6.07 & $8.87(10.47-6.78)$ & 13.83 \\
Temp Bond NE (EF) & $12.91(2.54) \mathrm{a}$ & 8.86 & $13.07(15.08-10.98)$ & 17.04 \\
\hline
\end{tabular}

ANOVA followed by the Bonferroni's test. Different letters indicate statistically significant difference $(\mathrm{p}<0.05)$.

\section{Discussion}

The temporary restoration phase is a reliable indicator of the clinical long-term success of the definitive restorations, because it helps to clear all the doubts that usually arise during treatment, like defining the shape, contour, vertical dimension and aesthetics of the definitive restorations (18). However, retention of the temporary cement should be adequate to maintain 
the restoration in function, but low enough to allow easy removal of the temporary restoration before the final restoration (5). In this context, tensile strength tests are often used and they consist in the use of a load required for the removal of crowns during the traction movement (17).

The present study initially evaluated the tensile strength of temporary crowns as they were cemented with four temporary cements (Table 2). G1 (eugenol-containing cement) showed the worst tensile strength while the G4 (eugenol-free cement) and $\mathrm{G} 2$ (eugenol-containing cement) showed the best results and both were similar to each other. Therefore, zinc-oxide eugenol-free cement does not seem to be associated with higher tensile strength, unlike observed by Kim et al. (19). These authors evaluated the tensile strength of temporary crowns cemented on implant abutment (metal substrate) and showed significantly higher values for eugenol-free temporary cement (Temp Bond $\mathrm{NE}$, Kerr) when compared to eugenol-containing cement (Temp Bond, Kerr).

Despite the presence of residual particles of the temporary cements, some authors believe that these residual particles may affect the bond strength of resin cements, in consequence of the reduction of surface free $\vec{s}$ energy $(4,7)$. In general, residual temporary cements might act as a barrier that inhibits the interactions between acidic functional monomers and inorganic components of dentin (4). Previous studies using scanning electron microscopy $(4,20,21)$ and atomic force microscopy (3) reported that remnants of temporary materials remain on dentin surfaces, even after mechanical cleaning and etching with 37\% phosphoric acid. However, some studies reported that these remnants are not sufficient to interfere with the bond strength of these adhesive systems and resin cements, whether eugenol-containing or not $(22,23)$.

Conversely, many studies showed that eugenol-

Table 2. Tensile strength values (kgf) of the groups after cementation with resin cement

\begin{tabular}{|c|c|c|c|c|}
\hline $\begin{array}{l}\text { Group } \\
(\mathrm{n}=9)\end{array}$ & Mean (SD) & Minimum & $\begin{array}{c}\text { Median } \\
\text { (Q75 - Q25) }\end{array}$ & Maximum \\
\hline Provy (EC) & $\begin{array}{c}164.44 \\
(31.23) \mathrm{a}\end{array}$ & 123.37 & $\begin{array}{c}155.84(179.18 \\
-147.60)\end{array}$ & 231.02 \\
\hline $\begin{array}{l}\text { Temp } \\
\text { Cem (EC) }\end{array}$ & $\begin{array}{c}120.68 \\
(48.27) \mathrm{ab}\end{array}$ & 67.32 & $\begin{array}{c}104.52(175.89 \\
-82.60)\end{array}$ & 188.25 \\
\hline $\begin{array}{l}\text { RelyX } \\
\text { Temp } \\
\text { NE (EF) }\end{array}$ & $\begin{array}{c}103.04 \\
(26.09) \mathrm{ab}\end{array}$ & 66.20 & $\begin{array}{c}104.56(120.32 \\
-77.92)\end{array}$ & 145.76 \\
\hline $\begin{array}{l}\text { Temp } \\
\text { Bond } \\
\text { NE (EF) }\end{array}$ & $\begin{array}{c}88.48 \\
(21.83) \mathrm{b}\end{array}$ & 52.43 & $\begin{array}{c}88.04(108.80 \\
-70.55)\end{array}$ & 118.15 \\
\hline
\end{tabular}

ANOVA followed by the Bonferroni test. Different letters indicate statistically significant difference $(p<0.05)$. containing cements significantly reduced bond strength of resin cements $(3,7,10,12,24)$. A possible explanation for this is the high affinity of eugenol to free radicals, producing chemical inhibition of the polymerization of resin materials. Thus, eugenol competes with the monomers for union to the initiators of polymerization, preventing complete reaction and affecting the mechanical properties of the adhesive and resin cement $(9,13,14)$. The negative effect of eugenol on polymerization of resin cements occurs even in rather small quantities due to its high capacity of diffusion into dentin (14). Fujisawa (14) and Ganss and Jung (22) affirmed that the concentration of eugenol in waste of temporary cements is so small that it would not cause any adverse effect on the adhesive bond and resin cements.

Unlike most studies in the literature, this research simulated a very common clinical situation in which metal crowns were cemented into a cast metal core. Based on this, the influence of eugenol-containing temporary cements in the bond strength of self-adhesive resin cement was evaluated. The results of tensile strength of the $\mathrm{Ni}-\mathrm{Cr}$ copings showed statistically significant difference $(p<0.05)$ only between G1 (Eugenol-containing, Provy, Dentsply) and $\mathrm{G} 4$ (Eugenol-free, Temp Bond ${ }^{\circledR} \mathrm{NE}$, Kerr Corp) (Table 2). Despite the statistical difference between $\mathrm{G1}$ and $\mathrm{G} 4$, it cannot be stated that eugenol is the determining factor for higher tensile strength of copings observed in G1 because G2 (eugenol-containing) and G3 (eugenol-free) showed similar tensile strength values ( $p>0.05)$. Thus, the work hypothesis was confirmed by showing that temporary cements (eugenol-containing or eugenol-free) do not interfere in the bond strength of the self-adhesive resin cement into metal coronal substrate, suggesting that the observed statistical difference could be associated with other Provy cement components, not only eugenol. Moreover, it is possible to infer that the residual particles of temporary cements were more easily removed from the metal cast than from the dentin because dentin may absorb eugenol and interfere with polymerization rate changing the bond strength.

There are other mechanical and chemical methods that may effectively help removing temporary cements. Mosharraf et al. (25) showed that eugenol-containing temporary cements were easily removed by ultrasonic cleaning from the surface of cast restorations. In addition, Koch et al. (8) showed that phosphoric acid or ethylenediaminetetraacetic acid (EDTA) etching significantly reduced the amount of eugenol in dentin and this method may be an alternative to cleaning metal surfaces before cementation with resin cements.

Further investigations with similar experimental design should be performed to bring more information about the interference of temporary cements on the tensile strength 
of indirect restorations to the metal substrates, since a wide majority of studies evaluate the bond strength to dentin.

In conclusion, the Provy eugenol-containing temporary cement was associated with the best bond strength of the resin cement when $\mathrm{Ni}-\mathrm{Cr}$ copings were cemented to cast metal cores. However, eugenol cannot be considered as a determining factor in increased bond strength, since the other tested cements ( 1 eugenol-containing and 2 eugenol-free) were similar.

\section{Resumo}

Esta pesquisa avaliou a influência dos cimentos temporários (contendo eugenol [CE]ou livre de eugenol[LE]) na resistência à tração de copingsde $\mathrm{Ni}-\mathrm{Cr}$ fixados com cimento resinoso auto-adesivo sobre substrato coronário metálico. Trinta e seis coroas provisórias foram divididas em 4 grupos $(n=9)$ de acordo com os cimentos temporários: Provy, Dentsply (contendo eugenol), Temp Cem, Vigodent (contendo eugenol), RelyXTemp NE, 3M ESPE (livre de eugenol) andTemp Bond NE, KerrCorp (livre de eugenol). Após 24 h da cimentação temporária, testes de resistência à tração foram realizados em uma máquina universal de ensaios, com velocidade de $0,5 \mathrm{~mm} / \mathrm{min}$. e célula de carga de $1 \mathrm{kN}$ (100 kgf). Em seguida, os núcleos metálicos fundidos foram limpos por meio de raspagem com cureta ejatos de ar. Trinta e seis copings de $\mathrm{Ni}-\mathrm{Cr}$ foram cimentados sobre os núcleos metálicos com cimento resinoso auto-adesivo (RelyX U200,3M ESPE). Testes de resistência à tração foram novamente realizados. Na cimentação provisória, Temp Bond NE $(12,91 \pm 2,54)$ e Temp Cem $(12,22 \pm 2,96)$ apresentaram os maiores valores de resistência à tração e foram estatisticamente semelhantes entre si $(p>0,05)$. Diferença estatisticamente significante $(p<0.05)$ foi observada apenas entre Provy $(164,44 \pm 31,23)$ e Temp Bond NE $(88,48 \pm 21,83)$ após cimentação dos copingsdeNi- $\mathrm{Cr}$ com cimento resinoso auto-adesivo. Além disso, Temp Cem $(120,68 \pm 48,27)$ e RelyX Temp NE $(103,04 \pm 26,09)$ mostraram valores intermediários de resistência à tração. Em conclusão, o cimento temporário contendo eugenol, Proxy, foi associado com a mais alta resistência de união do cimento resinoso, quando os copingsde $\mathrm{Ni}$ $\mathrm{Cr}$ foram cimentados sobre os núcleos metálicos fundidos. Entretanto, o eugenol não pode ser considerado como um fator determinante no aumento da resistência de união, já que outros cimentos testados (1 contendo eugenol e 2 livres de eugenol) foram semelhantes.

\section{Acknowledgements}

This investigation was supported by The São Paulo Research Foundation (FAPESP) (grant \#2010/01546-9).

\section{References}

1. Habib B, von Fraunhofer JA, Driscoll CF. Comparison of two luting agents used for the retention of cast dowel and cores. J Prosthodont 2005;14:164-169.

2. Mak YF, Lai SC, Cheung GS, Chan AW, Tay FR, Pashley DH. Microtensile bond testing of resin cements to dentin and an indirect resin composite. Dent Mater 2002;18:609-621.

3. Ribeiro JC, Coelho PG, Janal MN, Silva NR, Monteiro AJ, Fernandes CA. The influence of temporary cements on dental adhesive systems for luting cementation. J Dent 2011;39:255-262.

4. Takimoto $M$, Ishii $R$, lino $M$, Shimizu $Y$, Tsujimoto A, Takamizawa $T$, et al.. Influence of temporary cement contamination on the surface free energy and dentine bond strength of self-adhesive cements. J Dent 2012;40:131-138.

5. Rosenstiel SF, Land MF, Crispin BJ. Dental luting agents: A review of the current literature. J Prosthet Dent 1998;80:280-301.

6. Kanakuri $\mathrm{K}, \mathrm{Kawamoto} \mathrm{Y}, \mathrm{Matsumura} \mathrm{H}$. Influence of temporary cement remnant and surface cleaning method on bond strength to dentin of a composite luting system. J Oral Sci 2005;47:9-13.
7. Erdemir A, Eldeniz AU, Belli S. Effect of temporary filling materials on repair bond strengths of composite resins. J Biomed Mater Res B Appl Biomater 2008;86:303-309.

8. Koch T, Peutzfeldt A, Malinovskii V, Flury S, Haner R, Lussi A. Temporary zinc oxide-eugenol cement: eugenol quantity in dentin and bond strength of resin composite. Eur J Oral Sci 2013;121:363-369.

9. Yap AU, Shah KC, Loh ET, Sim SS, Tan CC. Influence of eugenolcontaining temporary restorations on bond strength of composite to dentin. Oper Dent 2001;26:556-561.

10. Carvalho $C N$, de Oliveira Bauer JR, Loguercio AD, Reis A. Effect of ZOE temporary restoration on resin-dentin bond strength using different adhesive strategies. J Esthet Restor Dent 2007;19:144-152.

11. Okada H, Ishida Y, Noguchi H, Ryukata I, Nagayama K. Development of a new temporary luting agent consisting of PEMA and eugenol--residue ratio and bond strength of luting cements for abutment materials. Dent Mater J 2009;28:261-266.

12. Silva JP, Queiroz DM, Azevedo LH, Leal LC, Rodrigues JL, Lima AF, et al. Effect of eugenol exposure time and post-removal delay on the bond strength of a self-etching adhesive to dentin. Oper Dent 2011;36:6671.

13. Spohr AM, Correr Sobrinho L, Consani S, Sinhoreti MA, Borges GA. Effect of refrigeration on tensile bond strength of three adhesive systems. Braz Dent J 2001;12:75-79.

14. Fujisawa $\mathrm{S}$, Kadoma $\mathrm{Y}$. Action of eugenol as a retarder against polymerization of methyl methacrylate by benzoyl peroxide. Biomaterials 1997;18:701-703.

15. Terata $R$, Yoshinaka S, Nakashima K, Kubota M. Effect of resinous temporary material on tensile bond strength of resin luting cement to tooth substrate. Dent Mater J 1996;15:45-50.

16. Watanabe EK, Yamashita A, Yatani H, Ishikawa K, Suzuki K. Improvement in the tensile bond strength between resin cement and dentin surfaces after temporary cement application. Int J Prosthodont 1998;11:203-211.

17. Peixoto RF, Hermanson MP, Pupim D, Rodrigues RC, Antunes RP, Mattos MD. Tensile strength of $\mathrm{Ni}-\mathrm{Cr}$ copings subjected to inner surface sandblasting using different cementing agents: An in vitro study. Acta Odontol Scand 2015. [Epub ahead of print DOI: 10.3109/00016357.2015.1050602].

18. Aykent F, Usumez A, Ozturk AN, Yucel MT. Effect of provisional restorations on the final bond strengths of porcelain laminate veneers. J Oral Rehabil 2005;32:46-50.

19. Kim Y, Yamashita J, Shotwell JL, Chong KH, Wang HL. The comparison of provisional luting agents and abutment surface roughness on the retention of provisional implant-supported crowns. J Prosthet Dent 2006;95:450-455.

20. Watanabe EK, Yatani H, Ishikawa K, Suzuki K, Yamashita A. Pilot study of conditioner/primer effects on resin-dentin bonding after provisional cement contamination using SEM, energy dispersive x-ray spectroscopy, and bond strength evaluation measures. J Prosthet Dent 2000;83:349-355

21. Grasso CA, Caluori DM, Goldstein GR, Hittelman E. In vivo evaluation of three cleansing techniques for prepared abutment teeth. J Prosthet Dent 2002;88:437-441.

22. Ganss $C$, Jung M. Effect of eugenol-containing temporary cements on bond strength of composite to dentin. Oper Dent 1998;23:55-62.

23. Peutzfeldt $A$, Asmussen E. Influence of eugenol-containing temporary cement on bonding of self-etching adhesives to dentin. J Adhes Dent 2006;8:31-34

24. Fiori-Junior M, Matsumoto W, Silva RA, Porto-Neto ST, Silva JM. Effect of temporary cements on the shear bond strength of luting cements. J Appl Oral Sci 2010;18:30-36.

25. Mosharraf R, Soleimani B, Sanaee-Nasab M. A comparison of two methods of removing zinc oxide-eugenol provisional cement residue from the internal surface of cast restorations. J Contemp Dent Pract 2009;10:27-34. 